\title{
Evaluation of Attractant Composition, Application Rate, and Trap Type for Potential Mass Trapping of Ips typographus (L.)
}

\author{
Tobias Heber*, Christiane E. Helbig (D), Sören Osmers and Michael G. Müller \\ Chair of Forest Protection, Institute of Silviculture and Forest Protection, Technische Universität Dresden, \\ Pienner Straße 8, 01737 Tharandt, Germany; christiane.helbig@tu-dresden.de (C.E.H.); \\ soeren.osmers@tu-dresden.de (S.O.); michael.mueller@tu-dresden.de (M.G.M.) \\ * Correspondence: tobias.heber@tu-dresden.de; Tel.: +49-351-463-44455
}

Citation: Heber, T.; Helbig, C.E.; Osmers, S.; Müller, M.G. Evaluation of Attractant Composition,

Application Rate, and Trap Type for Potential Mass Trapping of Ips typographus (L.). Forests 2021, 12, 1727. https://doi.org/10.3390/f12121727

Academic Editor: Dariusz

J. Gwiazdowicz

Received: 9 November 2021

Accepted: 4 December 2021

Published: 8 December 2021

Publisher's Note: MDPI stays neutral with regard to jurisdictional claims in published maps and institutional affiliations.

\begin{abstract}
This study focused on elucidating the possibilities of improving current trapping methods for Ips typographus (Linnaeus, 1758). Three field experiments were conducted simultaneously in one study area in the German federal state of Saxony. A comparison of six different commercial attractants revealed a significant superiority of Typosan ${ }^{\circledR}$, especially for adult beetles after hibernation in the phase of their first swarming. It also attracted fewer individuals of Thanasimus spp. than the other highly attractive products Pheroprax ${ }^{\circledR}$ and IT Ecolure Extra ${ }^{\circledR}$. Increasing the Pheroprax ${ }^{\circledR}$ application rate by using four instead of one dispenser in a single trap increased the total catch of I. typographus only by $15.5 \%$. In contrast, Thanasimus spp. catch increased by $195.5 \%$ when four dispensers were used. A test of different trap types showed a species-specific catching capability, with the 12-funnel WitaTrap ${ }^{\circledR}$ being the most effective in catching I. typographus. The quantity of Thanasimus spp. bycatch in multiple-funnel traps demonstrated the necessity of a selective mechanism to minimize impacts on predator populations. Although we were not able to identify new milestones towards mass trapping, this study contributes to necessary improvements of current trapping methods. Especially in future stands with a smaller share of Norway spruce (Picea abies Karsten, 1881) the weakened beetle population in spring could be effectively reduced by properly conducted mass trapping.
\end{abstract}

Keywords: Ips typographus; Thanasimus spp.; bark beetles; Norway spruce; mass trapping; attractants; release rate; trap type; integrated pest management

\section{Introduction}

Climate change impacts on forests are a worldwide phenomenon [1-3]. For Europe, an increase in extreme weather events is predicted to cause physiological stress for trees and forests as well as promoting the reproduction of forest insects with high damage potential $[4,5]$. Consequently, millions of hectares of forest land are annually damaged by insects and pathogens in Europe [6]. The eight-toothed spruce bark beetle (Ips typographus Linnaeus, 1758) particularly benefits from more frequent droughts, storms, and rising temperatures $[1,7,8]$. The species is able to undergo eruptive population outbreaks and is known as the most destructive pest in forests of Norway spruce (Picea abies Karsten, 1881) where it has killed extensive areas in recent years $[7,9,10]$.

Enormous amounts of suitable breeding material following disastrous storms, a drought-induced raised susceptibility of trees and high temperatures accelerating the development of I. typographus increase the probability of outbreaks [1,11-13]. These factors coincided in Central Europe from 2017 to 2020. Six devastating storm events [14-19] and unprecedented hot and dry summers [20] gave rise to a perennial large-scale outbreak of I. typographus. In such situations, the species is able to overcome the defense mechanism of healthy trees and not depend on susceptible stands [7,21-23]. As a result, large amounts of calamity wood accumulated, especially in Germany, the Czech Republic, and Austria [24-26], which exceeded the capacity of the regular forestry and wood industry, thus resulting in severe logistical problems $[9,27]$. For example, in the German federal 
state of Saxony, unplanned wood logging due to bark beetle infestations alone added up to 2.2 million $\mathrm{m}^{3}$ in 2019, which is almost as much as the annual mean for Europe from 1950 to 2000 with 2.9 million $\mathrm{m}^{3}$ [26,28]. Historically, bark beetle induced calamities are a frequent phenomenon. A total of 7000 hectares of spruce forest were killed during an outbreak of I. typographus from 1781 to 1786 in the Harz mountains [29]. Several other eruptive population outbreaks followed in the 19th and 20th century in Europe [28,30,31].

Even though I. typographus is considered to be a crucial ecosystem engineer and keystone species in natural forests, its management in forests, serving ecological, social, and economic purposes, is often inevitable to sustain a multifunctional forestry [8]. Trap-based monitoring programs are an important part of managing spruce forests [13,32]. Since trap trees were replaced by artificial traps after the discovery of the species-specific aggregation pheromone of I. typographus [33,34], trapping methods have been constantly developed and improved [35-39]. Salvage logging and sanitation felling are based on the monitoring data and are still the most effective measures in bark beetle management $[11,13,32]$. Consequently, the enormous amount of unplanned logging caused a drop in wood prices due to a saturated wood market [9]. The preventive application of pheromone traps to protect spruce stands and avoid calamity logging has been, however, discussed intensively. Various studies have proven that effective trap-based management can prevent attacks by $I$. typographus and decrease unplanned logging [40-45]. In contrast, many studies exist in which no significant reduction in population sizes and protection of living trees were achieved by trapping despite great effort $[30,46,47]$, or where the cause for the decline in damage cannot be explicitly assigned to mass trapping [31,45]. The critical factor for success or failure appears to be the stage of population development in which mass trapping was conducted $[13,42]$. The increasing restrictions for the application of insecticides in forests due to strict formalities of the European Union [48] and the side effects of calamity logging draw interest to mass trapping options without insecticides. Such methods aim to reduce the population density of the target species in a way that secures the ecological, social, and economic objectives of the forest.

In our study we conducted alterations of current trapping methods for I. typographus to improve the state of knowledge for future mass trapping as part of bark beetle management. With regard to the "surveillance with the intent to control" approach by Vité (1989) [34], and in consideration of important antagonists, three main components of current monitoring techniques were tested concerning their potential for mass trapping of I. typographus. These are:

(1) attractant composition,

(2) application rate, and

(3) trap type.

\section{Materials and Methods}

\subsection{Study Site}

The study took place in Germany in the federal state of Saxony in the Tharandt forest from the 6 April 2020 to the 29 June 2020. Three different clearings were selected in the forest district Bärenfels between the villages of Grillenburg and Naundorf, north and south of the state road S194 and within a radius of $1700 \mathrm{~m}$ to ensure similar climate conditions. The study sites are located at an altitude of 400 to $430 \mathrm{~m}$ above sea level and are categorized as humid lower mountainous region. The mean annual temperature is $9.8^{\circ} \mathrm{C}$, long-term precipitation mean is $843 \mathrm{~mm}$, but was distinctly lower in 2018 (496.4 mm), 2019 $(676.1 \mathrm{~mm})$, and $2020(644.7 \mathrm{~mm})$. The distance between the three clearings was at least $100 \mathrm{~m}$ to avoid interdependence.

In the study area, a mass outbreak of I. typographus started in 2018 and has caused large amounts of calamity wood. The clearings selected for this study are the result of sanitation felling or salvage logging. The adjacent stands consist mainly of Norway spruce, 40 to 70 years old and colonizable by I. typographus. Scots pine (Pinus sylvestris), European larch (Larix decidua), and European beech (Fagus sylvatica) are secondary tree species. Silver birch 
(Betula pendula), common ash (Fraxinus excelsior), sycamore maple (Acer pseudoplatanus), and European alder (Alnus glutinosa) are present as single trees.

\subsection{Species Identification}

I. typographus, Thanasimus femoralis (Zetterstedt, 1828), and T. formicarius (Linnaeus, 1758) were defined as target species, which are considered to be two of the most important antagonists of I. typographus $[49,50]$. In the process of further analyses, T. femoralis and T. formicarius were regularly grouped as Thanasimus spp. Pityogenes chalcographus (Linnaeus, 1761), another important bark beetle on Norway spruce [51-53] was additionally included in the trap trial analysis to study species-specific behavior within the group of bark beetles. A stereomicroscope Zeiss Stemi 508 was used for species identification with keys [54-57].

I. typographus was identified and counted individually at least in the first collection of all three trials. With increasing numbers, individual counting became too time-consuming and catches were quantified using a mean weight value. For its determination, catches were dried and 50 individuals of each trap in each collection were weighed using a precision balance (Kern EW 150-3M) to derive a trap-specific mean beetle weight. Individuals of the genus Thanasimus were always identified and counted individually.

\subsection{Study Design}

\subsubsection{General Design}

The experiments were based on the trap island methodology [58], which was also applied in other field trials with bark beetles [59,60]. For each of the three trials five trap islands were set up with a minimum distance of $50 \mathrm{~m}$ to each other. Within a trap island the different test variants were arranged depending on the number of variants: an isosceles triangle for three, a square for four, and a circle for more than four variants. The circular arrangement enables the integration of more than four variants while ensuring that each trap has only two adjacent traps. Traps on the same trap island were spaced at least $10 \mathrm{~m}$ from each other. The distance between traps was set in a way to both guarantee a targeted approach of the insects to the respective variants to avoid mutual interference due to too narrow spacing [61] and to reduce the probability of catching different beetle populations on the same trap island [58]. Traps were activated on the 6 April 2020 by attaching the attractants inside the trap analogous to Miller (2013) [62]. Trap catches were then collected six times in a 14-day interval beginning with the first on the 20 April 2020. Saturated benzoic acid solution with a drop of dishwashing detergent to lower surface tension was used as killing and preservative agent and renewed at every collection date. The attractants were replaced with a new attractant according to the specifications given by the manufacturer (Table 1 ).

\subsubsection{Attractant Composition Trial}

Since the first commercially produced attractant Pheroprax ${ }^{\circledR}$ in 1979 [34], various alternative attractants have been developed, differing in release rate and composition. Out of these, six were selected and tested regarding their attractivity to I. typographus as well as its antagonists T. femoralis and T. formicarius with Theysohn ${ }^{\circledR}$ slot traps (FLÜGEL $\mathrm{GmbH}$, Lower Saxony, Germany). All products have been included in several other studies. Pheroprax ${ }^{\circledR}$ was specifically examined [63] and has been the standard attractant in many other experiments $[41,61,64,65]$. It is also part of the standardized bark beetle monitoring applied in the study area [26]. The attractants IT Ecolure classic ${ }^{\circledR}$, IT Ecolure Extra ${ }^{\circledR}$, and IT Ecolure Mega ${ }^{\circledR}$ are also known from literature $[44,66,67]$ as well as Ipsowit ${ }^{\circledR}[68-71]$ and Typosan ${ }^{\circledR}$ [70-72]. Table 1 summarizes the duration of attractivity, release rate and composition of the tested products. The release rate has been determined by weekly weighing the products with a precision balance (Kern EW 150-3M), while the composition of the attractants was obtained from literature [71], where only information for IT Ecolure Extra ${ }^{\circledR}$ was available. Since it had the same manufacturer as IT Ecolure classic ${ }^{\circledR}$ and IT Ecolure Mega ${ }^{\circledR}$, information was transferred. However, it seems that only the pheromonal 
components were specified [71]. Cis-Verbenol was mentioned as the only constituent for the Ecolure products, but since it is crystalline and solid in pure state [73], it needs a solvent, which was not listed.

Table 1. Composition of products tested in the attractant composition trial modified after Sramel et al. (2021) [71].

\begin{tabular}{|c|c|c|c|c|c|c|}
\hline Dispenser & $\begin{array}{l}\text { IT Ecolure } \\
\text { Classic }^{\circledR}\end{array}$ & $\begin{array}{c}\text { IT Ecolure } \\
\text { Extra }^{\circledR}\end{array}$ & $\begin{array}{l}\text { IT Ecolure } \\
\text { Mega }^{\circledR}\end{array}$ & Ipsowit $^{\circledR}$ & Pheroprax ${ }^{\circledR}$ & Typosan $^{\circledR}$ \\
\hline $\begin{array}{l}\text { Duration of } \\
\text { attractivity } \\
\text { (weeks) }\end{array}$ & $8-10$ & $6-8$ & $18-20$ & $6-8$ & $6-8$ & 10 \\
\hline $\begin{array}{l}\text { Release rate } \\
\qquad(\mathrm{mg} / \mathrm{d})\end{array}$ & 36.5 & 70.4 & 69.5 & 16.2 & 33.8 & 30.0 \\
\hline Composition & (S)-cis-Verbenol & (S)-cis-Verbenol & (S)-cis-Verbenol & $\begin{array}{c}\text { S-Ipsdienol, } \\
(S) \text {-cis-Verbenol }\end{array}$ & $\begin{array}{c}\text { S-Ipsdienol, } \\
\text { (S)-cis-Verbenol } \\
\text { 2-Methyl-3- } \\
\text { buten-1-ol }\end{array}$ & $\begin{array}{l}\text { (S)-cis- } \\
\text { Verbenol, } \\
\text { 2-Methyl-3- } \\
\text { buten-1-ol }\end{array}$ \\
\hline Dispenser type & $\begin{array}{c}\text { blotter } \\
\text { (aluminum foil) }\end{array}$ & $\begin{array}{c}\text { blotter } \\
\text { (aluminum foil) }\end{array}$ & $\begin{array}{c}\text { blotter } \\
\text { (aluminum foil) }\end{array}$ & $\begin{array}{c}\text { blotter } \\
\text { (membrane foil) }\end{array}$ & ampoule & $\begin{array}{c}\text { blotter } \\
\text { (membrane foil) }\end{array}$ \\
\hline Producer & Fytofarm & Fytofarm & Fytofarm & Witasek & BASF & Sintagro AG \\
\hline $\begin{array}{l}\text { Country of } \\
\text { production }\end{array}$ & Slovakia & Slovakia & Slovakia & Austria & Germany & Switzerland \\
\hline
\end{tabular}

\subsubsection{Application Rate Trial}

In this experiment, the attractivity of different dosages of Pheroprax ${ }^{\circledR}$ was tested. In addition to single-baited Theysohn ${ }^{\circledR}$ slot traps the dispenser was applied twice and four times within one trap. The attractants were individually distributed in the center of the trap over the entire trap width.

\subsubsection{Trap Type Trial}

The development of trap types began parallel to the first commercial attractants in the late 1970s [34] resulting in a variety of existing types, two of which were tested in this study. WitaTraps ${ }^{\circledR}$ (WITASEK PflanzenSchutz GmbH, Kärnten, Austria) designed after Lindgren (1983) [74] with 8, 12, and 16 funnels were compared with the Theysohn ${ }^{\circledR}$ slot trap [75], in terms of trapping efficacy. By reducing the number of funnels from the standard 12 to 8 and increasing it to 16 , we wanted to examine whether the size of the trap surface affects its trapping efficacy. All tested trap types were baited with one dispenser of Pheroprax ${ }^{\circledR}$. $P$. chalcographus individuals were only identified and counted for the first two collections.

\subsection{Data Analysis}

Statistical analysis was performed using the R software, version 4.1 .1 with the ggplot2, ggpubr, PMCMRplus, pgirmess, plyr, tidyverse, and readxl packages [76-82]. First absolute numbers of caught beetles were transformed into relative ones. This approach has the advantage of compensating different population densities as well as varying trapping periods during the study [58-60]. The relative values represent the percentage of caught individuals of one species in one variant per trap island and collection date. The numbers of trap islands and collections were used as replications, assuming that new individuals emerge every week [58-60]. The data was then tested for normal distribution using the Shapiro-Wilk test and for homogeneity of variances using the Levene test. If these conditions were not met, a Kruskal-Wallis test was applied as a nonparametric test for independent samples. Subsequently pairwise Iman-Conover tests located the significant differences between the variants. A $p$ value of 0.05 was applied as threshold of significance.

\section{Results}

During the study period, a total of 1,245,835 individuals of I. typographus were caught in the traps on the three study sites, with most individuals in the application rate trial 
and the fewest in the attractant composition trial. Figure 1 shows the numbers during the course of the study. A first maximum was reached at the collection on the 4 May, a second more distinctive one followed six weeks later.

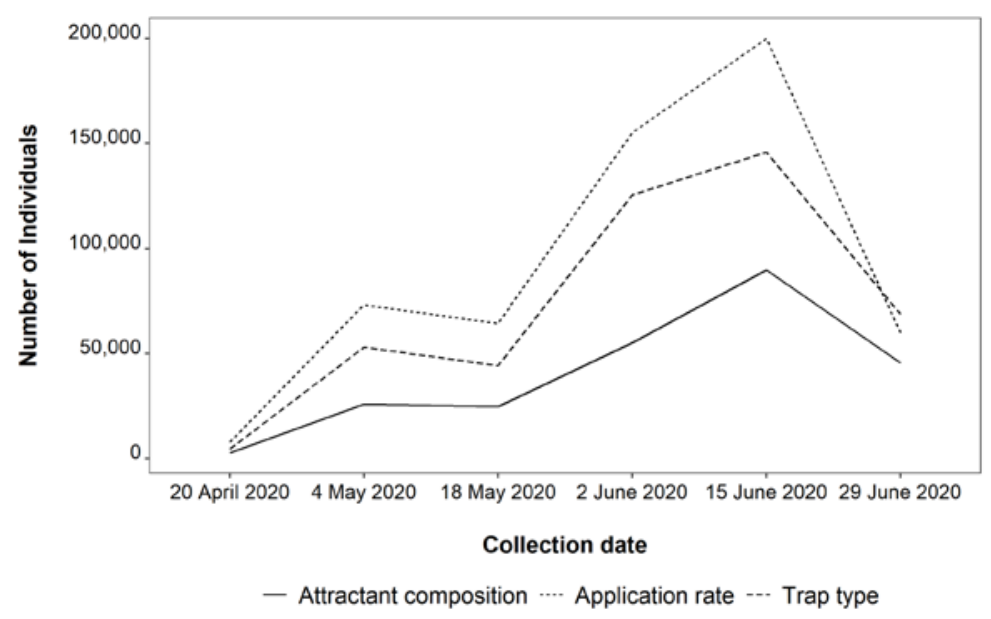

Figure 1. Total number of I. typographus caught in the three trials within the study period.

\subsection{Attractant Composition Trial}

A total of 243,491 individuals of I. typographus were caught in this trial. Additionally, 211 specimen of T. formicarius and 163 specimen of T. femoralis were present. In terms of attractivity to I. typographus the products can be distinguished in two groups: a group with higher trapping numbers consisting of Typosan ${ }^{\circledR}$ with a median of $23.5 \%$, IT Ecolure Extra ${ }^{\circledR}$ with a median of $18.7 \%$, Pheroprax ${ }^{\circledR}$ with a median of $16.7 \%$, a group with lower trapping results consisting of IT Ecolure classic ${ }^{\circledR}$ with a median of $14.8 \%$, Ipsowit ${ }^{\circledR}$ with a median of $13.5 \%$, and IT Ecolure Mega ${ }^{\circledR}$ with a median of $13.3 \%$ (Figure 2a). All products of the first group caught significantly more individuals than Ipsowit ${ }^{\circledR}$ and IT Ecolure Mega ${ }^{\circledR}$ (Table A1 in Appendix A), while IT Ecolure classic ${ }^{\circledR}$ took a middle position. Within the first group Typosan ${ }^{\circledR}$ stood out from the other two products with significant higher catching numbers than Pheroprax ${ }^{\circledR}$.



(a)

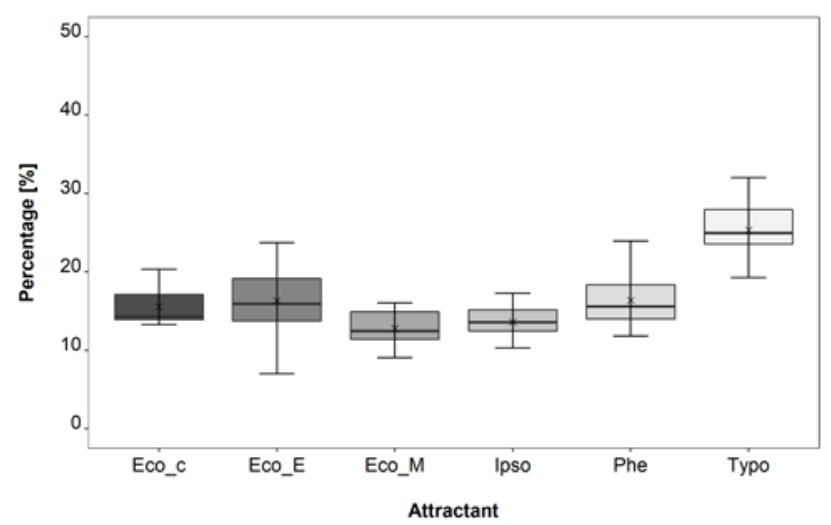

(b)

Figure 2. Mean percentage of I. typographus catches in Theysohn ${ }^{\circledR}$ slot traps baited with different attractant products per trap island and collection date in the study period (a) 6 April 2020 to 29 June 2020,n=30; (b) 6 April 2020 to 18 May 2020 , $n=15 ;$ Eco_c $=$ IT Ecolure classic ${ }^{\circledR}$, Eco_E $=$ IT Ecolure Extra ${ }^{\circledR}$, Eco_M $=$ IT Ecolure Mega ${ }^{\circledR}$, Ipso $=$ Ipsowit $^{\circledR}$, Phe $=$ Pheroprax $^{\circledR}$, Typo $=$ Typosan $^{\circledR}$.

Typosan ${ }^{\circledR}$, Pheroprax ${ }^{\circledR}$, and IT Ecolure Extra ${ }^{\circledR}$ also showed superior results in terms of absolute trapping numbers. Their total catches of $44,357,45,542$, and 47,378 individuals of I. typographus represent increases of $29.9 \%, 33.4 \%$, and $38.8 \%$ compared to the least effective 
product Ipsowit ${ }^{\circledR}$, which caught 34,146 individuals. Although the absolute number of individuals for Typosan ${ }^{\circledR}$ was lower than for Pheroprax ${ }^{\circledR}$ and IT Ecolure Extra ${ }^{\circledR}$, a significantly higher attractivity of Typosan, considering relative numbers, is given. This is a result of the first three trapping periods displayed in Figure 2b, in which Typosan ${ }^{\circledR}$ is clearly superior and caught significantly more individuals of I. typographus than any other product (Table A2 in Appendix A), which is also reflected in the absolute numbers for this period. In total, catches of I. typographus were distinctively lower during the first three collections with 53,119 individuals than in the second half of the trial, when 190,372 individuals were caught. However, during the second half only three significant differences were verifiable (Table A3 in Appendix A).

Regarding the trapping results for T. femoralis and T. formicarius all three Ecolure products showed a high attractivity for both species (Figure 3). Together they caught $82.9 \%$ of all 374 Thanasimus spp. individuals in this trial, with IT Ecolure classic ${ }^{\circledR}$ and IT Ecolure Extra ${ }^{\circledR}$ attracting significantly more individuals than Ipsowit ${ }^{\circledR}$ and Typosan ${ }^{\circledR}$ (Table A4 in Appendix A).

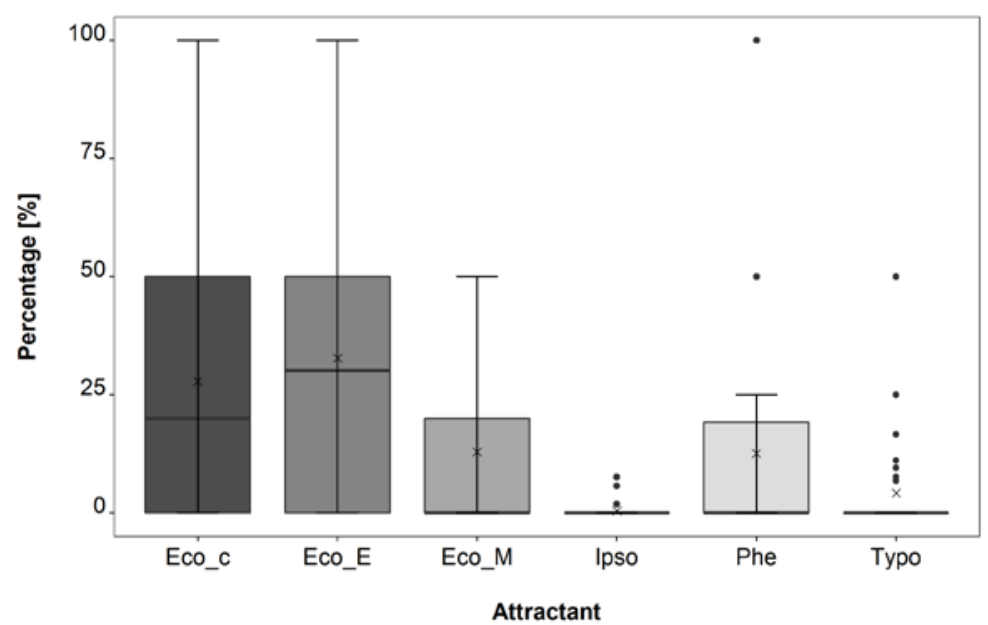

Figure 3. Mean percentage of Thanasimus spp. catches in Theysohn ${ }^{\circledR}$ slot traps baited with different attractants per trap island and collection date in the study period from 6 April 2020 to 19 June 2020, Eco_c $=$ IT Ecolure classic ${ }^{\circledR}$, Eco_E $=$ IT Ecolure Extra ${ }^{\circledR}$, Eco_M $=$ IT Ecolure Mega ${ }^{\circledR}$, Ipso $=$ Ipsowit $^{\circledR}$, Phe $=$ Pheroprax $^{\circledR}$, Typo $=$ Typosan $^{\circledR}, n=30$.

\subsection{Application Rate Trial}

In this trial a total of 560,598 individuals of I. typographus were caught, whereas T. femoralis and T. formicarius were present with 474 and 599 individuals, respectively.

Increasing the number of Pheroprax ${ }^{\circledR}$ dispensers per trap led to an increase in attractivity for I. typographus (Figure 4). Thus, the median of traps with a single Pheroprax ${ }^{\circledR}$ was $31.8 \%$, with two Pheroprax ${ }^{\circledR} 32.5 \%$ and the fourfold application $34.7 \%$. The statistical analysis showed significantly higher trapping percentages of the variant with four Pheroprax ${ }^{\circledR}$ compared to the variants with a single or two Pheroprax ${ }^{\circledR}$ (Table A5 in Appendix A), whereas no significant difference existed between the single and double application variants. However, increasing the application of Pheroprax ${ }^{\circledR}$ by four times only resulted in a $15.5 \%$ increase in absolute numbers of caught I. typographus compared to the regular single application.

Applying four dispensers of Pheroprax ${ }^{\circledR}$ in one trap resulted in a significant increase in Thanasimus spp. bycatch by 195.5\% from 199 to 588 individuals (Table A6 in Appendix A). Double application of Pheroprax ${ }^{\circledR}$ increased trap attractivity for the considered antagonists as well (Figure 5), however, this was not statistically significant. 




Figure 4. Mean percentage of I. typographus catches in Theysohn ${ }^{\circledR}$ slot traps baited with different numbers of Pheroprax ${ }^{\circledR}$ dispensers per trap island and collection date in the study period from 6 April 2020 to 29 June 2020, P_1 = one Pheroprax ${ }^{\circledR}, P_{-} 2=$ two Pheroprax $^{\circledR}, P_{-} 4=$ four Pheroprax ${ }^{\circledR}$, $n=30$.

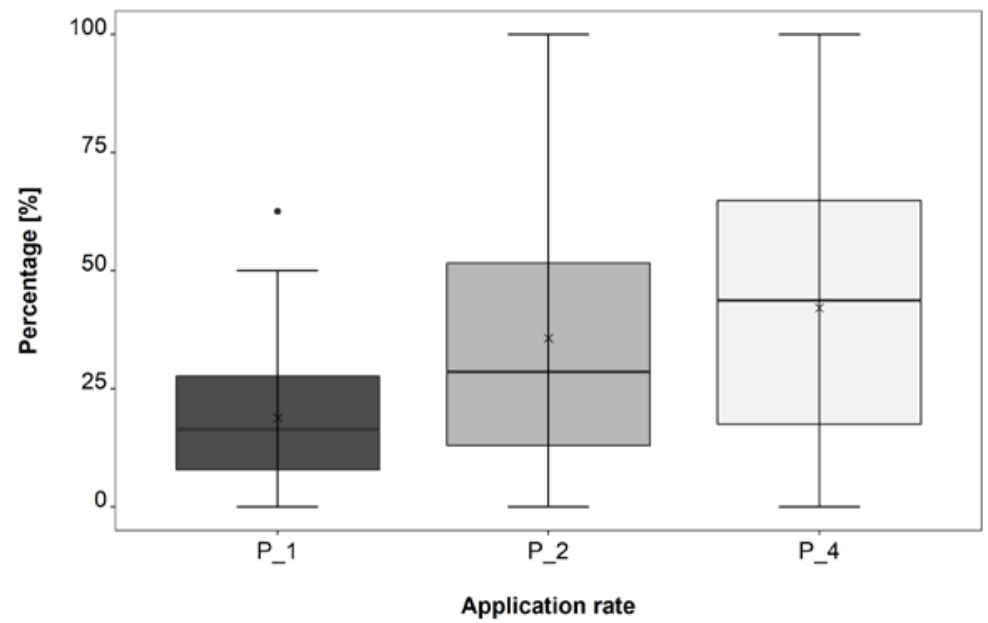

Figure 5. Mean percentage of Thanasimus spp. catches in Theysohn ${ }^{\circledR}$ slot traps baited with different numbers of Pheroprax ${ }^{\circledR}$ dispensers per trap island and collection date in the study period from 6 April 2020 to 29 June 2020, P_1 = one Pheroprax ${ }^{\circledR}, P \_2=$ two Pheroprax ${ }^{\circledR}, P \_4=$ four Pheroprax ${ }^{\circledR}$, $n=30$.

\subsection{Trap Type Trial}

A total of 441,746 individuals of I. typographus, 492 individuals of T. femoralis and 490 individuals of $T$. formicarius were caught in this trial comparing trapping efficacy of different trap types.

The tested trap types showed clear differences in their trapping efficacy for I. typographus (Figure 6) and revealed a significant superiority of the 12-funnel WitaTrap ${ }^{\circledR}$ (Table A7 in Appendix A) with a median of $30.4 \%$, whereas the median for the 16 -funnel WitaTrap ${ }^{\circledR}$ was $23.9 \%$, for the Theysohn ${ }^{\circledR}$ slot trap $22.1 \%$, and for the 8 -funnel WitaTrap ${ }^{\circledR} 20.4 \%$. Both increase and reduction in the number of funnels led to a decrease in trapping numbers compared to the standard 12-funnel WitaTrap ${ }^{\circledR}$. With regard to absolute numbers, the 12-funnel WitaTraps ${ }^{\circledR}$ caught $45.5 \%$ more individuals than Theysohn ${ }^{\circledR}$ slot traps.

The results for $P$. chalcographus, with 7225 individuals, the second most frequent species in the first two collections, differed from those of I. typographus (Figure 7). With a total of 3012 individuals the Theysohn ${ }^{\circledR}$ slot trap was the most effective trap type for this species (Table A8 in Appendix A). 


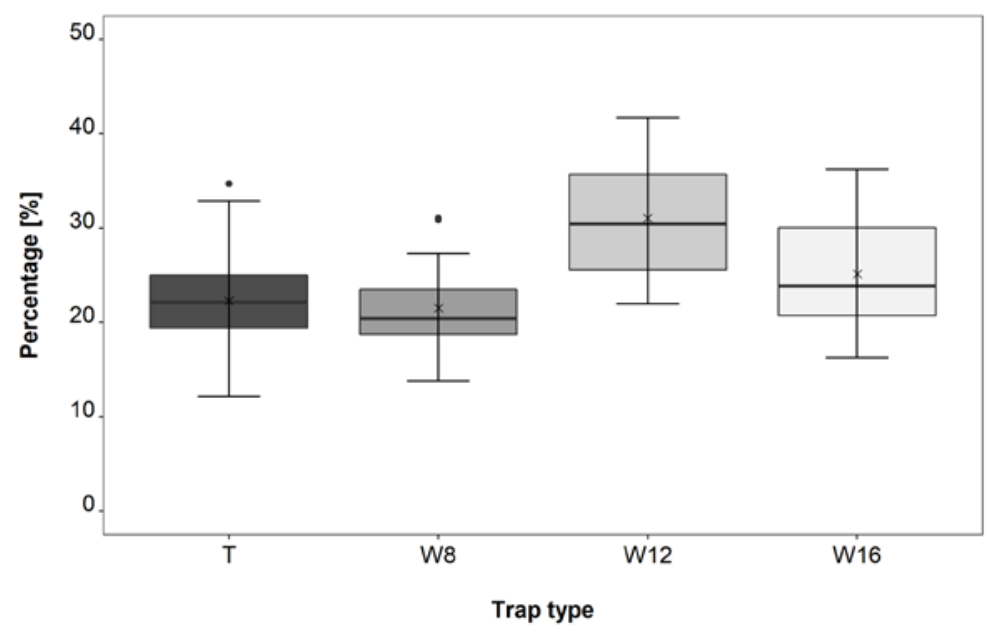

Figure 6. Mean percentage of I. typographus catches in different trap types per trap island and collection date in the study period from 6 April 2020 to 29 June 2020, T = Theysohn ${ }^{\circledR}$ slot trap, W8 $=8$-funnel WitaTrap ${ }^{\circledR}, \mathrm{W} 12=12$-funnel WitaTrap ${ }^{\circledR}$, W16 $=16$-funnel WitaTrap ${ }^{\circledR}, n=30$.

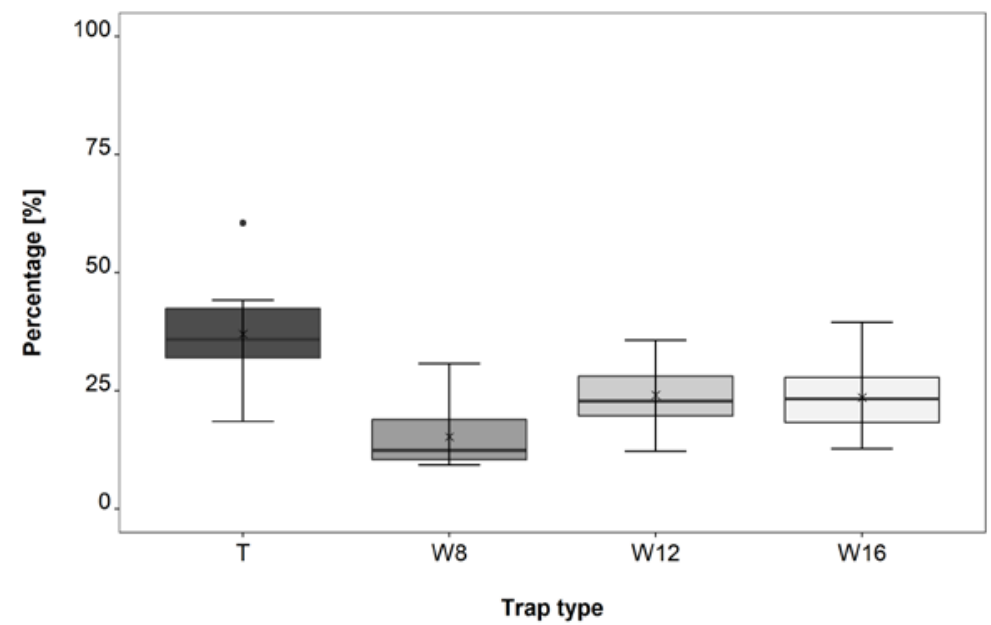

Figure 7. Mean percentage of $P$. chalcographus catches to different trap types per trap island and collection date in the study period from 6 April 2020 to 29 June 2020, T = Theysohn ${ }^{\circledR}$ slot trap, W8 = 8-funnel WitaTrap ${ }^{\circledR}$, W12 $=12$-funnel WitaTrap ${ }^{\circledR}$, W16 $=16$-funnel WitaTrap ${ }^{\circledR}, n=30$.

The majority of Thanasimus spp. showed a preference for the WitaTrap ${ }^{\circledR}$ types (Figure 8), whereas the Theysohn ${ }^{\circledR}$ slot trap caught the fewest individuals of these antagonists with a median of $8.2 \%$. Within the three WitaTrap ${ }^{\circledR}$ types, the more funnels were installed, the more individuals of Thanasimus spp. were caught. The median of the 8-funnel WitaTrap ${ }^{\circledR}$ was $18.9 \%$, of the 12-funnel WitaTrap ${ }^{\circledR} 24.2 \%$, and of the 16-funnel WitaTrap ${ }^{\circledR}$ $37.8 \%$, with the latter catching significantly more individuals than any other tested trap type (Table A9 in Appendix A). 


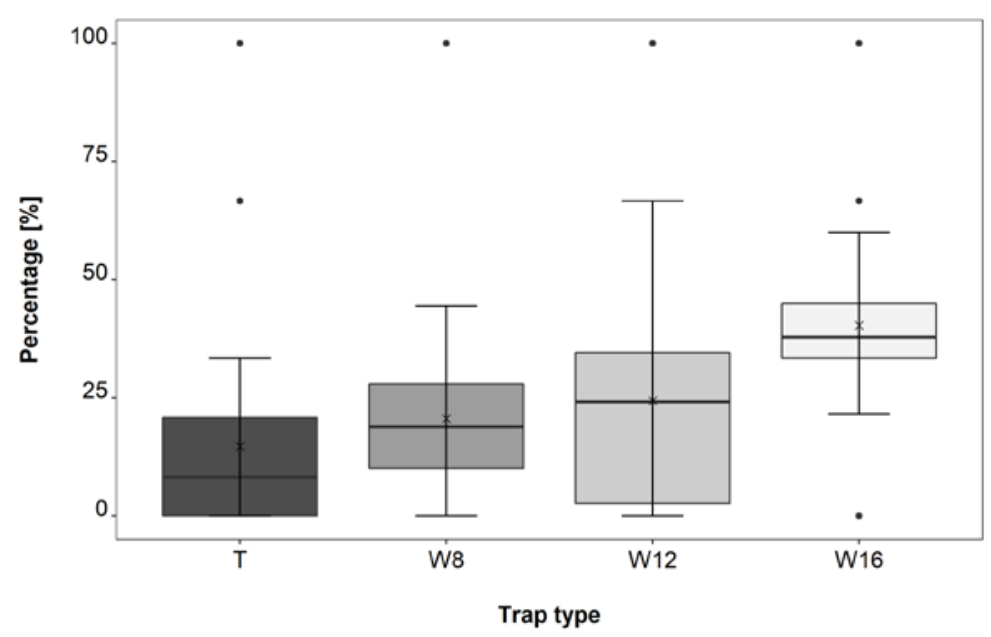

Figure 8. Mean percentage of Thanasimus spp. catches in different trap types per trap island and collection date in the study period from 6 April 2020 to 29 June 2020, T = Theysohn ${ }^{\circledR}$ slot trap, W8 $=8$-funnel WitaTrap ${ }^{\circledR}, \mathrm{W} 12=12$-funnel WitaTrap ${ }^{\circledR}$, W16 $=16$-funnel WitaTrap ${ }^{\circledR}, n=30$.

\section{Discussion}

\subsection{Attractant Composition Trial}

After the development of the first commercial pheromone attractant for I. typographus in 1979 [34], the manufacturing of other products with varying compositions and release rates followed. According to the results of this study, they also differ significantly in their attractivity to I. typographus. The compositions of the attractants are based on the components of the species-specific aggregation pheromone. Based on findings on olfactory communication of Ips confusus (LeConte, 1876) [83-85], the attractivity of the three genus-specific components Ipsenol, Ipsdienol, and cis-Verbenol was proved under natural conditions [86]. The existence of an aggregation pheromone was also demonstrated for I. typographus and further components were discovered [87-89]. After advances in the knowledge on the complex chemical communication of bark beetles [90], 2-Methyl-3-buten-1-ol was identified as the species-specific pheromonal component [33]. The variation in trapping results among the tested products illustrates the potential of attractant composition to optimize the trapping efficacy for I. typographus.

All products tested in this study contain merely a part of the entire known bouquet of attractive components of the I. typographus aggregation pheromone (Table 1). The reason for this is their main application in the monitoring of the species $[13,32,71,91]$, which only requires the attraction of a sufficient number of beetles. The best trapping results were obtained by Typosan ${ }^{\circledR}$, which is the only product containing nothing more than the synergistically acting pheromone components cis-Verbenol and 2-Methyl-3-buten-1-ol. While the former acts as long-range orientation component of the aggregation pheromone, the latter has been indicated as landing stimulus [92]. In contrast, Pheroprax ${ }^{\circledR}$ and Ipsowit ${ }^{\circledR}$ contain Ipsdienol, which is known to trigger a reaction on receptor neurons [93] and has an aggregating effect [94]. However, the addition of Ipsdienol to a combination of cis-Verbenol and 2-Methyl-3-buten-1-ol does not increase attractivity $[61,95,96]$, which is supported by the results of this study. Cis-Verbenol is the only pheromone component in the Ecolure products. It might be the absence of 2-Methyl-3-buten-1-ol that causes a lower attractivity of these products for I. typographus, which was particularly apparent for IT Ecolure classic ${ }^{\circledR}$ and IT Ecolure Mega ${ }^{\circledR}$. The high efficacy of IT Ecolure Extra ${ }^{\circledR}$, on the other hand, could be explained by its high release rate, which is the highest in the group of most attractive products. I. typographus catches tend to increase with increasing release rate of pheromones $[34,61,64,67,97]$. Apparently, the lower release rate of Typosan ${ }^{\circledR}$ and Pheroprax ${ }^{\circledR}$ compared to IT Ecolure Extra ${ }^{\circledR}$ was compensated by a more suitable attractant composition. 
The aforementioned high efficacy of Typosan ${ }^{\circledR}$ was manifested particularly in the first half of the trial. Assuming a start of swarming at an air temperature of $16.5^{\circ} \mathrm{C}[98,99]$, the first three collections consisted of overwintered adult beetles from the previous year. Since favorable conditions allow a complete development from egg to emerging young beetle within 29 days [100], the last three collections consisted partly of individuals of the first generation. This hypothesis is supported by the PHENIPS model [101] based on the climate data of the station at Dippoldiswalde-Reinberg located close to the study site. The combination of cis-Verbenol and 2-Methyl-3-buten-1-ol in Typosan ${ }^{\circledR}$ seems to have the most attractive effect on overwintered adult beetles, whereas the emerging young beetles of the first generation appear to be much less selective when approaching the traps. Such intraspecific variability in olfactory perception is already known for I. typographus. A distinction between primary and secondary attraction referring to different attack phases of I. typographus was established [90]. Moreover, an increased attractivity of monoterpenes for pioneer beetles was assumed [102], as well as specific primary attractants favoring the initial selection of a breeding habitat were described [93]. Even during colonization of a host tree the composition of produced pheromones varies considerably [103]. The overwintered generation, weakened by winter mortality of approximately $50 \%$, continues to be exposed to high mortality during the first swarming, which is more intense than the flight of subsequent generations $[7,104]$. The increased risk possibly leads to an increased olfactory sensitivity of overwintered adult beetles compared to the vital young beetles of the first generation.

In contrast to the high attractivity of Typosan ${ }^{\circledR}$ to I. typographus a low attractivity to its antagonists T. femoralis and T. formicarius was found, thus emphasizing its suitability for potential mass trapping. The reciprocal behavior to I. typographus seems unusual at first, since Thanasimus spp. responds to similar volatiles as its prey, so similar results were expectable [63,105-107]. However, for Thanasimus spp. as generalists [108] genus-specific semiochemicals such as Ipsdienol, Ipsenol, or cis-Verbenol [86] are more important than species-specific attractants such as 2-Methyl-3-buten-1-ol [105]. Thanasimus spp. do not have olfactory receptor cells for the latter, triggering no reaction as single component for these species $[105,106]$. Furthermore, cis-Verbenol elicits a lower antennal response in Thanasimus spp. than Ipsenol and Ipsdienol [105]. Both cis-Verbenol and 2-Methyl-3-buten1-ol are pheromone components in Typosan ${ }^{\circledR}$ and explain its low attractivity to Thanasimus spp. However, the Ecolure products containing solely cis-Verbenol showed the highest attractivity. This does not seem to be a behavior induced by attractant composition but by higher release rates. The results of the application rate trial show that Thanasimus spp. reacts strongly to a higher attractant concentration. This behavior can be transferred to the results of the attractant composition trial as cause for the high catches of Thanasimus spp. with the Ecolure products characterized by the highest release rates and low catches with Ipsowit ${ }^{\circledR}$, which has the lowest release rate of the tested products.

Similar results regarding the trapping of I. typographus with Typosan ${ }^{\circledR}$ can be found with the evidence of its higher attractivity compared to Pheroprax ${ }^{\circledR}$ [72] and its relatively low number of bycatch [71]. However, Pheroprax ${ }^{\circledR}$ is considered to be an effective attractant for I. typographus when compared with different products in other studies $[44,71,109]$. IT Ecolure Mega ${ }^{\circledR}$ was previously described as comparatively less attractive for I. typographus [110] according to the results of our study. On the contrary, numerous studies contradict our results. In Šramel et al. (2021) the lowest trapping numbers of I. typographus were achieved with Typosan ${ }^{\circledR}$ compared to Pheroprax ${ }^{\circledR}$, IT Ecolure Extra ${ }^{\circledR}$, Ipstyp ${ }^{\circledR}$, and Ipsowit ${ }^{\circledR}$ [71]. In Otto (2005), Typosan ${ }^{\circledR}$ performed significantly worse than Pheroprax ${ }^{\circledR}$ [70]. IT Ecolure classic ${ }^{\circledR}$ achieved higher trapping results in Nakládal et al. (2013) than IT Ecolure Mega ${ }^{\circledR}$ [110], whereas no significant differences between both products were detected in our study. Zahradník and Zahradníková (2014) described IT Ecolure Mega ${ }^{\circledR}$ as the most efficient attractant [109], while in this study it belongs to the group of less effective products. In studies by Pfister $(1997,1998)$, Ipsowit ${ }^{\circledR}$ showed similar trapping results as Pheroprax ${ }^{\circledR}[68,69]$, which could not be confirmed in our study. The reasons for 
these differences in trapping results of various products are likely to be found in differing methodological approaches. In the above-mentioned studies trapping was conducted over the entire activity phase of I. typographus, while this study only considered twelve weeks of its flight starting with the first swarming of overwintered adult beetles in spring. Moreover, the experimental design used in this study $[58,59]$ was not applied in the other studies.

\subsection{Application Rate Trial}

The increased release rate by the application of more than one Pheroprax ${ }^{\circledR}$ dispenser resulted in higher trapping numbers of I. typographus, which is consistent with other studies $[61,64,67]$. However, while a proportional increase in trapping numbers when increasing the release rate was observed in previous studies [61], the fourfold application of Pheroprax ${ }^{\circledR}$ in our study only resulted in an increase of $15.5 \%$ with regard to absolute numbers. Instead of a proportional relationship between application rate and attractivity, trapping numbers followed the principle of the Weber-Fechner law, which states that "linear increments in sensation are proportional to the logarithm of stimulus magnitude" [111]. A behavior according to the Weber-Fechner law was observed for several insect species, such as Drosophila melanogaster (Meigen, 1830), Hylobius abietis (Linnaeus, 1758), Trypodendron lineatum (Olivier, 1795) [112-114], and also I. typographus. For this species the number of caught beetles cannot be increased perpetually by increasing the release rate of an attractant. Instead it asymptotically approaches a saturation level, since very high release rates do not exert relevant effects on behavior [34,92].

Thanasimus spp. exhibited a stronger reaction to a high application of Pheroprax ${ }^{\circledR}$ than I. typographus. This behavior is consistent with their general ecology, since such predators aggregate at sites of increased prey abundance. They follow an aggregation reaction that describes an increase in local population densities of predators due to increased prey abundance $[115,116]$. Such a response was observed for Nemozoma elongatum (Linnaeus, 1761) as predator of Taphrorychus bicolor (Herbst, 1793) [117] and applied in the form of allochthonous kairomones as part of a nature-based bark beetle management [58]. In this context, the increased release of pheromonal components in our trial simulated a higher abundance of I. typographus. The antennal receptors of Thanasimus spp. have the same olfactory sensitivity as their potential prey [63,105-107]. Thus, they are able to perceive the semiochemicals emitted by Pheroprax ${ }^{\circledR}$ and aggregate at sites of higher concentrations.

\subsection{Trap Type Trial}

The results of this trial showed that trapping numbers of I. typographus can be significantly influenced by the choice of the trap type. The previously known superiority of the multiple funnel trap with 12 funnels over the Theysohn ${ }^{\circledR}$ slot trap [38,39] was confirmed. The reduction to eight funnels caused a decline in trapping efficacy, since trap surface and trapping numbers correlate positively [34,39]. Correspondingly, increasing the trap surface by adding more funnels should result in higher numbers of caught individuals. However, this effect only occurred when comparing the 8-funnel with the 12-funnel WitaTrap ${ }^{\circledR}$, while trapping efficacy declined when using the 16-funnel WitaTrap ${ }^{\circledR}$. This can be explained with the increasing trap height by adding additional funnels. Insects are then able to spread their wings within the trap and leave it before reaching the trapping container like discussed in other studies [74,118]. The trap design also affects the emission of semiochemicals causing higher or lower release rates into the environment [32,62,118,119]. Multiple-funnel traps probably allow a higher emission of the used attractants due to the larger gaps between funnels compared to the Theysohn ${ }^{\circledR}$ slot trap. Even the position of the dispenser within the trap can affect trapping efficacy $[62,119]$, which is why attractants in this trial were always placed in the same position.

In contrast to I. typographus we found a significant preference of the Theysohn ${ }^{\circledR}$ slot trap for $P$. chalcographus. A species-specific trapping efficacy of different trap types was described in many other studies [39,118,120-123]. With regard to I. typographus and P. chalcographus a possible explanation is the visual similarity of trap design and preferred 
beetle habitat, since both species use visual cues for orientation [124,125]. I. typographus primarily colonizes the trunk below the crown of trees, while P. chalcographus usually breeds in the canopy [126]. On one hand, multiple-funnel traps better resemble a tree trunk than the Theysohn ${ }^{\circledR}$ slot trap due to their vertical, elongated appearance and are preferred by I. typographus. On the other hand, the Theysohn ${ }^{\circledR}$ slot trap has similarities to the silhouette of a tree canopy due to its rectangular, planar shape, and is therefore more attractive to P. chalcographus.

Thanasimus spp. showed similar preferences as I. typographus favoring WitaTraps ${ }^{\circledR}$. The higher trapping numbers of antagonists in multiple-funnel traps are consistent with the results of other studies $[39,127]$. The critical factor seems to be the visual orientation used by Thanasimus spp. to locate its prey [125]. Since I. typographus is the more important prey, the trap that more closely resembles its habitat is also more attractive to Thanasimus spp. In addition, a potentially better attractant emission from WitaTraps ${ }^{\circledR}$ might contribute to the higher numbers of T. femoralis and T. formicarius in these traps. In contrast to I. typographus Thanasimus spp. is apparently not able to spread its wings and escape before dropping into the trapping container, resulting in higher numbers the more funnels were installed. The amount of caught antagonists emphasizes the necessity of having more selective trap types, which has also been mentioned in former studies [44], and has already been developed for Ips sexdentatus [128]. Thanasimus spp. is essential for the natural regulation of bark beetle populations $[49,50,129]$ requiring highly selective mass trapping devices to minimize the impacts on predators [130].

\section{Conclusions}

The data of our study prove that an optimization of the analyzed three-directional approach to mass trapping results in a significant increase in catches of I. typographus. The attractant composition seems to be the most powerful tool to reach further improvements, especially since neither of the tested attractants contains all known pheromone components. Increasing the application rate had an unwanted side effect on antagonists similar to some of the tested trap types. Improving the selectivity of traps is required if mass trapping programs are to be implemented. Furthermore, trap types showed a species-specific efficacy exacerbating the chances of a universally applicable mass trapping technology for bark beetles.

The high efficacy of Typosan ${ }^{\circledR}$ for hibernated I. typographus shows a promising time dependent reaction to volatiles. Further research such as gas chromatographic analysis of attractants and electroantennogram responses are crucial to understand the differences in olfactory receptors of hibernating adult beetles and their offspring. It is desirable to develop a mass trapping attractant specifically designed for the first swarming period of I. typographus when the population size is at its lowest level due to high winter mortality. During early spring pheromone traps are highly attractive to individuals in search for breeding sites, meaning it is the best time for mass trapping. A temporary increase in the application rate for this first swarming period could contribute to a more pronounced reduction of population sizes, while trap types with a high selectivity would spare antagonists. This would increase the chances to sustainably reduce the population of I. typographus to a level not harmful for standing trees or at the least mitigate the peak of a mass outbreak. Hence, mass trapping of I. typographus without insecticides might be applicable in the future. Considering the forest conversion in Central Europe from monocultures towards mixed stands, a reduction in local outbreaks and protection of smaller spruce stands has higher chances to succeed than under current circumstances. In future stands, it might be economically sensible to protect rare spruce wood by traps. It remains disputable if mass trapping can cause an abrupt end to ongoing eruptive population outbreaks in pure spruce stands on a large scale, even though successful small-scale operations are known. However, the significant increase in total trap catches achieved by the three-directional approach of this study does not seem sufficient to reduce the number of beetles in an outbreak situation 
effectively. Thus, the replacement of salvage logging and sanitation felling as most effective treatments in bark beetle management by mass trapping is not yet an option.

Author Contributions: Conceptualization, M.G.M., T.H. and C.E.H.; methodology, T.H., C.E.H. and M.G.M.; software, T.H. and S.O.; validation, M.G.M., T.H. and C.E.H.; formal analysis, T.H.; investigation, T.H. and S.O.; resources, M.G.M. and T.H.; data curation, T.H. and S.O.; writingoriginal draft preparation, T.H.; writing - review and editing, T.H., C.E.H. and M.G.M.; visualization, T.H., C.E.H. and S.O.; supervision, M.G.M.; project administration, M.G.M., C.E.H. and T.H.; funding acquisition, M.G.M. and C.E.H. All authors have read and agreed to the published version of the manuscript.

Funding: This research was carried out within the ReBek project funded by Fachagentur Nachwachsende Rohstoffe e. V., project management agency of the German Federal Ministry of Food and Agriculture (grant number 22019917).

Acknowledgments: We want to thank the whole team of the Chair of Forest Protection for their support, advice, and the productive and warmhearted working atmosphere. Furthermore, we thank Staatsbetrieb Sachsenforst for providing the study sites and forester Maik Schumann for the easygoing collaboration.

Conflicts of Interest: The authors declare no conflict of interest. The funders had no role in the design of the study; in the collection, analyses, or interpretation of data; in the writing of the manuscript, or in the decision to publish the results.

\section{Appendix A}

Table A1. Significance table of the results of pairwise comparisons with the Iman-Conover test for the attractant composition trial from 6 April 2020 to 29 June 2020 for I. typographus, $n=30$, Eco_c $=$ IT Ecolure classic ${ }^{\circledR}$, Eco_E $=$ IT Ecolure Extra ${ }^{\circledR}$, Eco_M $=$ IT Ecolure Mega ${ }^{\circledR}$, Ipso = Ipsowit ${ }^{\circledR}$, Phe $=$ Pheroprax ${ }^{\circledR}$, Typo $=\operatorname{Typosan}^{\circledR}, 0.05 \geq{ }^{*}>0.01 \geq{ }^{* *}>0.001 \geq * * *$.

\begin{tabular}{lcc}
\hline Pairwise Comparison & $p$ Value & Significance Code \\
\hline Eco_E-Eco_M & $2.5 \times 10^{-5}$ & $* * *$ \\
Eco_E-Ipso & 0.0001 & $* * *$ \\
Phe-Eco_M & 0.00045 & $* * *$ \\
Phe-Ipso & 0.00156 & $* *$ \\
Typo-Eco_c & 0.00013 & $* * *$ \\
Typo-Eco_M & $2.3 \times 10^{-10}$ & $* * *$ \\
Typo-Ipso & $1.4 \times 10^{-9}$ & $* * *$ \\
Typo-Phe & 0.04111 & $*$ \\
\hline
\end{tabular}

Table A2. Significance table of the results of pairwise comparisons with the Iman-Conover test for the attractant composition trial from 6 April 2020 to 18 May 2020 for I. typographus, $n=15$, Eco_C $=$ IT Ecolure classic ${ }^{\circledR}$, Eco_E $=$ IT Ecolure Extra ${ }^{\circledR}$, Eco_M $=$ IT Ecolure Mega ${ }^{\circledR}$, Ipso = Ipsowit ${ }^{\circledR}$, Phe $=$ Pheroprax $^{\circledR}$, Typo $=$ Typosan $^{\circledR}, 0.05 \geq{ }^{*}>0.01 \geq^{* *}>0.001 \geq{ }^{* * *}$.

\begin{tabular}{lcc}
\hline Pairwise Comparison & $\boldsymbol{p}$ Value & Significance Code \\
\hline Eco_c-Eco_M & 0.0413 & $*$ \\
Eco_E-Eco_M & 0.0098 & $*$ \\
Phe-Eco_M & 0.0135 & $*$ \\
Typo-Eco_c & $9.4 \times 10^{-6}$ & $* * *$ \\
Typo-Eco_E & $5.9 \times 10^{-5}$ & $* * *$ \\
Typo-Eco_M & $1.0 \times 10^{-11}$ & $* * *$ \\
Typo-Ipso & $5.3 \times 10^{-10}$ & $* * *$ \\
Typo-Phe & $4.0 \times 10^{-5}$ & $* *$ \\
\hline
\end{tabular}


Table A3. Significance table of the results of pairwise comparisons with the Iman-Conover test for the attractant composition trial from 19 May 2020 to 29 June 2020 for I. typographus, $n=15$,

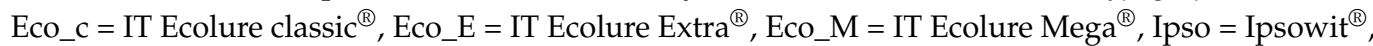
Phe $=$ Pheroprax $^{\circledR}$, Typo $=\operatorname{Typosan}^{\circledR}, 0.05 \geq *>0.01 \geq * * 0.001 \geq * * *$.

\begin{tabular}{lcc}
\hline Pairwise Comparison & $p$ Value & Significance Code \\
\hline Eco_E-Eco_M & 0.0052 & $* *$ \\
Eco_E-Ipso & 0.0022 & $*$ \\
Phe-Ipso & 0.0277 & $*$ \\
\hline
\end{tabular}

Table A4. Significance table of the results of pairwise comparisons with the Iman-Conover test for the attractant composition trial from 6 April 2020 to 29 June 2020 for Thanasimus spp., $n=30$, Eco_c $=$ IT Ecolure classic ${ }^{\circledR}$, Eco_E $=$ IT Ecolure Extra ${ }^{\circledR}$, Eco_M $=$ IT Ecolure Mega ${ }^{\circledR}$, Ipso $=$ Ipsowit $^{\circledR}$, Phe $=$ Pheroprax $^{\circledR}$, Typo $=\operatorname{Typosan}^{\circledR}, 0.05 \geq *>0.01 \geq * * 0.001 \geq * * *$.

\begin{tabular}{lcc}
\hline Pairwise Comparison & $p$ Value & Significance Code \\
\hline Eco_c-Ipso & $1.6 \times 10^{-5}$ & $* * *$ \\
Eco_c-Typo & 0.0013 & $* *$ \\
Eco_E-Ipso & $1.9 \times 10^{-7}$ & $* *$ \\
Eco_E-Phe & 0.0441 & $*$ \\
Eco_E-Typo & $2.8 \times 10^{-5}$ & $*$ \\
Eco_M-Ipso & 0.03 & $* *$ \\
\hline
\end{tabular}

Table A5. Significance table of the results of pairwise comparisons with the Iman-Conover test for the application rate trial from 6 April 2020 to 29 June 2020 for I. typographus, $n=30$, P_1 = one Pheroprax ${ }^{\circledR}$ applied, P_2 = two Pheroprax ${ }^{\circledR}$ applied, P_4 = four Pheroprax ${ }^{\circledR}$ applied, $0.05 \geq^{*}>0.01 \geq^{* *}>0.001 \geq^{* * *}$.

\begin{tabular}{lcc}
\hline Pairwise Comparison & $p$ Value & Significance Code \\
\hline P_4-P_1 & 0.0059 & $*$ \\
P_4-P_2 & 0.0108 & $*$ \\
\hline
\end{tabular}

Table A6. Significance table of the results of pairwise comparisons with the Iman-Conover test for the application rate trial from 6 April 2020 to 29 June 2020 for Thanasimus spp., $n=30$, P_1 = one Pheroprax ${ }^{\circledR}$ applied, P_2 = two Pheroprax ${ }^{\circledR}$ applied, P_4 = four Pheroprax ${ }^{\circledR}$ applied, $0.05 \geq^{*}>0.01 \geq{ }^{* *}>0.001 \geq * * *$

\begin{tabular}{lcc}
\hline Pairwise Comparison & $p$ Value & Significance Code \\
\hline P_4-P_1 & 0.0052 & $* *$ \\
\hline
\end{tabular}

Table A7. Significance table of the results of pairwise comparisons with the Iman-Conover test for the trap type trial from 6 April 2020 to 29 June 2020 for I. typographus, $n=30$, W8 = 8-funnel WitaTrap ${ }^{\circledR}, \mathrm{W} 12=12$-funnel WitaTrap ${ }^{\circledR}, \mathrm{W} 16=16$-funnel WitaTrap ${ }^{\circledR}, \mathrm{T}=$ Theysohn $^{\circledR}$ slot trap, $0.05 \geq{ }^{*}>0.01 \geq{ }^{* *}>0.001 \geq * *$.

\begin{tabular}{lcc}
\hline Pairwise Comparison & $p$ Value & Significance Code \\
\hline W12-T & $6.1 \times 10^{-8}$ & $* * *$ \\
W12-W8 & $6.7 \times 10^{-10}$ & $* * *$ \\
W12-W16 & 0.00046 & $* *$ \\
W16-W8 & 0.02047 & $*$ \\
\hline
\end{tabular}


Table A8. Significance table of the results of pairwise comparisons with the Iman-Conover test for the trap type trial from 6 April 2020 to 29 June 2020 for P. chalcographus, $n=10$, W8 = 8-funnel WitaTrap $^{\circledR}, \mathrm{W} 12=12$-funnel WitaTrap ${ }^{\circledR}, \mathrm{W} 16=16$-funnel WitaTrap ${ }^{\circledR}, \mathrm{T}=$ Theysohn $^{\circledR}$ slot trap, $0.05 \geq^{*}>0.01 \geq^{* *}>0.001 \geq^{* * *}$.

\begin{tabular}{lcc}
\hline Pairwise Comparison & $p$ Value & Significance Code \\
\hline T-W8 & $1.0 \times 10^{-5}$ & $* * *$ \\
T-W12 & 0.044 & $*$ \\
T-W16 & 0.028 & $*$ \\
W12-W8 & 0.041 & $*$ \\
\hline
\end{tabular}

Table A9. Significance table of the results of pairwise comparisons with the Iman-Conover test for the trap type trial from 6 April 2020 to 29 June 2020 for Thanasimus spp., $n=30$, W8 = 8-funnel WitaTrap ${ }^{\circledR}, \mathrm{W} 12=12$-funnel WitaTrap ${ }^{\circledR}, \mathrm{W} 16=16$-funnel WitaTrap ${ }^{\circledR}, \mathrm{T}=$ Theysohn $^{\circledR}$ slot trap, $0.05 \geq *>0.01 \geq * *>0.001 \geq * * *$

\begin{tabular}{lcc}
\hline Pairwise Comparison & $p$ Value & Significance Code \\
\hline W16-T & $1.6 \times 10^{-6}$ & $* * *$ \\
W16-W8 & 0.0009 & $* * *$ \\
W16-W12 & 0.0186 & $*$ \\
\hline
\end{tabular}

\section{References}

1. Jakoby, O.; Lischke, H.; Wermelinger, B. Climate change alters elevational phenology patterns of the European spruce bark beetle (Ips typographus). Glob. Chang. Biol. 2019, 25, 4048-4063. [CrossRef]

2. Dale, V.H.; Joyce, L.A.; McNulty, S.; Neilson, R.P. The interplay between climate change, forests, and disturbances. Sci. Total Environ. 2000, 262, 201-204. [CrossRef]

3. Millar, C.I.; Stephenson, N.L.; Stephens, S.L. Climate change and forests of the future: Managing in the face of uncertainty. Ecol. Appl. 2007, 17, 2145-2151. [CrossRef] [PubMed]

4. La Porta, N.; Capretti, P.; Thomsen, I.M.; Kasanen, R.; Hietala, A.M.; von Weissenberg, K. Forest pathogens with higher damage potential due to climate change in Europe. Can. J. Plant Pathol. 2008, 30, 177-195. [CrossRef]

5. Mezei, P.; Jakuš, R.; Pennerstorfer, J.; Havašová, M.; Škvarenina, J.; Ferenčík, J.; Slivinský, J.; Bičárová, S.; Bilčík, D.; Blaženec, M.; et al. Storms, temperature maxima and the Eurasian spruce bark beetle Ips typographus-An infernal trio in Norway spruce forests of the Central European High Tatra Mountains. Agric. For. Meteorol. 2017, 242, 85-95. [CrossRef]

6. Ferretti, M. Criterion 2: Maintenance of Forest Ecosystem Health and Vitality. In State of Europe's Forests 2020; Raši, R., Ed.; Ministerial Conference on the Protection of Forests in Europe: Zvolen, Slovakia, 2020; pp. 52-87.

7. Netherer, S.; Kandasamy, D.; Jirosová, A.; Kalinová, B.; Schebeck, M.; Schlyter, F. Interactions among Norway spruce, the bark beetle Ips typographus and its fungal symbionts in times of drought. J. Pest Sci. 2021, 197, 1142. [CrossRef]

8. Müller, J.; Bußler, H.; Goßner, M.; Rettelbach, T.; Duelli, P. The European spruce bark beetle Ips typographus in a national park: From pest to keystone species. Biodivers. Conserv. 2008, 17, 2979-3001. [CrossRef]

9. Toth, D.; Maitah, M.; Maitah, K.; Jarolínová, V. The impacts of calamity logging on the development of spruce wood prices in czech forestry. Forests 2020, 11, 283. [CrossRef]

10. Sommerfeld, A.; Rammer, W.; Heurich, M.; Hilmers, T.; Müller, J.; Seidl, R. Do bark beetle outbreaks amplify or dampen future bark beetle disturbances in Central Europe? J. Ecol. 2021, 109, 737-749. [CrossRef] [PubMed]

11. Stadelmann, G.; Bugmann, H.; Meier, F.; Wermelinger, B.; Bigler, C. Effects of salvage logging and sanitation felling on bark beetle (Ips typographus L.) infestations. For. Ecol. Manag. 2013, 305, 273-281. [CrossRef]

12. Seidl, R.; Müller, J.; Hothorn, T.; Bässler, C.; Heurich, M.; Kautz, M. Small beetle, large-scale drivers: How regional and landscape factors affect outbreaks of the European spruce bark beetle. J. Appl. Ecol. 2015, 53, 530-540. [CrossRef]

13. Vanická, H.; Holuša, J.; Resnerová, K.; Ferenčík, J.; Potterf, M.; Véle, A.; Grodzki, W. Interventions have limited effects on the population dynamics of Ips typographus and its natural enemies in the Western Carpathians (Central Europe). For. Ecol. Manag. 2020, 470-471, 1-16. [CrossRef]

14. Haeseler, S. Sturmtief HERWART Sorgt am 28./29. Oktober 2017 für Orkanböen über Deutschland. 2017. Available online: https: / / www.dwd.de/DE/leistungen/besondereereignisse/stuerme/20171030_herwart_europa.pdf?_blob=publicationFile\&v=6 (accessed on 11 February 2021).

15. Haeseler, S. Sturmtief XAVIER Zieht am 5. Oktober 2017 mit Orkanböen über Deutschland. 2017. Available online: https://www.dwd.de/DE/leistungen/besondereereignisse/stuerme/20171009_sturmtief_xavier_deutschland.pdf?_blob= publicationFile\&v=4 (accessed on 11 February 2021). 
16. Haeseler, S. Orkantief FRIEDERIKE Wütet am 18. Januar 2018 über Europa. 2018. Available online: https://www.dwd. de/DE/leistungen/besondereereignisse/stuerme/20180123_friederike_europa.pdf?_blob=publicationFile\&v=9 (accessed on 11 February 2021).

17. Haeseler, S.; Bissoli, P.; Dassler, J.; Zins, V.; Kreis, A. Orkantief Sabine Löst am 09./10. Februar 2020 eine Schwere Sturmlage über Europa aus 2020. Available online: https:/ / www.dwd.de/DE/leistungen/besondereereignisse/stuerme/20200213_orkantief_ sabine_europa.pdf?_blob=publicationFile\&v=3 (accessed on 11 February 2021).

18. Haeseler, S.; Bissoli, P.; Lefebvre, C.; Dassler, J.; Zins, V. Serie von Sturmtiefs im März 2019 über Europa mit Orkanböen in Deutschland. 2019. Available online: https:/ /www.dwd.de/DE/leistungen/besondereereignisse/stuerme/20190320_sturmtiefs_ europa.pdf?_blob=publicationFile\&v=1 (accessed on 11 February 2021).

19. Lefebvre, C.; Bissoli, P.; Hafer, M.; Rocek, M. Sturmtief FABIENNE Bringt am 23. September 2018 Sturm und Regen, Deutscher Wetterdienst. 2018. Available online: https://www.dwd.de/DE/leistungen/besondereereignisse/stuerme/20180923_sturm_ fabienne.pdf?_blob=publicationFile\&v=4 (accessed on 11 February 2021).

20. Büntgen, U.; Urban, O.; Krusic, P.J.; Rybníček, M.; Kolář, T.; Kyncl, T.; Ač, A.; Koňasová, E.; Čáslavský, J.; Esper, J.; et al. Recent European drought extremes beyond Common Era background variability. Nat. Geosci. 2021, 14, 190-196. [CrossRef]

21. Schlyter, P.; Stjernquist, I.; Bärring, L.; Jönsson, A.; Nilsson, C. Assessment of the impacts of climate change and weather extremes on boreal forests in northern Europe, focusing on Norway spruce. Clim. Res. 2006, 31, 75-84. [CrossRef]

22. Ghimire, R.P.; Kivimäenpää, M.; Blomqvist, M.; Holopainen, T.; Lyytikäinen-Saarenmaa, P.; Holopainen, J.K. Effect of bark beetle (Ips typographus L.) attack on bark VOC emissions of Norway spruce (Picea abies Karst.) trees. Atmos. Environ. 2016, 126, 145-152. [CrossRef]

23. Hroššo, B.; Mezei, P.; Potterf, M.; Majdák, A.; Blaženec, M.; Korolyova, N.; Jakuš, R. Drivers of spruce bark beetle (Ips typographus) infestations on downed trees after severe windthrow. Forests 2020, 11, 1290. [CrossRef]

24. Hoch, G.; Steyrer, G.; Netherer, S. The outbreak of Ips typographus in Northern Austria. In Proceedings of the Forests' FutureConsequences of Bark Beetle Calamity for the Future of Forestry in Central Europe, Strnady, Czech Republic, 23 March 2021.

25. Knížek, M.; Liska, J.; Lubojacky, J. Recent spruce bark beetle calamity in Czechia. In Proceedings of the Forests' FutureConsequences of Bark Beetle Calamity for the Future of Forestry in Central Europe, Strnady, Czech Republic, 23 March 2021.

26. Sonnemann, S.; Otto, L.F.; Matschulla, F.; Hodel, M. Forest damages in the federal state of Saxony during the extreme years 2018-2019. In Proceedings of the Forests' Future-Consequences of Bark Beetle Calamity for the Future of Forestry in Central Europe, Strnady, Czech Republic, 23 March 2021.

27. Mergl, V.; Zemánek, T.; Šušnjar, M.; Klepárník, J. Efficiency of harvester with the debarking head at logging in spruce stands affected by bark beetle outbreak. Forests 2021, 12, 1348. [CrossRef]

28. Schelhaas, M.-J.; Nabuurs, G.-J.; Schuck, A. Natural disturbances in the European forests in the 19th and 20th centuries. Glob. Chang. Biol. 2003, 9, 1620-1633. [CrossRef]

29. Gmelin, J.F. Gmelin's Abhandlung über die Wurmtroknis; Crusius: Leipzig, Germany, 1787.

30. Pfeffer, A.; Skuhravy, V. Der Buchdrucker (Ips typographus L.) (Col., Scolytidae) und seine Problematik in der Tschechischen Republik. Anz. Schädlkd. Pflanzenschutz Umweltschutz 1995, 68, 151-152. [CrossRef]

31. Bakke, A. The recent Ips typographus outbreak in Norway-Experiences from a control program. Holarct. Ecol. 1989, 12, 515-519. [CrossRef]

32. Ozcan, G.E.; Cicek, O.; Enez, K.; Yildiz, M. A new approach to determine the capture conditions of bark beetles in pheromonebaited traps. Biotechnol. Biotechnol. Equip. 2014, 28, 1057-1064. [CrossRef]

33. Bakke, A. Field response to a new pheromonal compound isolated from Ips typographus. Naturwissenschaften 1977, 64, 98-99. [CrossRef]

34. Vité, J.P. The European struggle to control Ips typographus-Past, present and future. Ecography 1989, 12, 520-525. [CrossRef]

35. Weslien, J.; Annila, E.; Bakke, A.; Bejer, B.; Eidmann, H.H.; Narvestad, K.; Nikula, A.; Ravn, H.P. Estimating risks for spruce bark beetle (Ips typographus (L.)) damage using pheromone-baited traps and trees. Scand. J. For. Res. 1989, 4, 87-98. [CrossRef]

36. Weslien, J. Monitoring Ips typographus (L.) populations and forecasting damage. J. Appl. Entomol. 1992, 114, 338-340. [CrossRef]

37. Bakke, A. Deploying pheromone-baited traps for monitoring Ips typographus populations1. Z. Für Angew. Entomol. 1985, 99, 33-39. [CrossRef]

38. Galko, J.; Gubka, A.; Vakula, J.; Brutovský, D. Comparison of catches of the spruce bark beetle (Ips typographus L.) (Coleoptera: Scolytidae) in pheromone traps of Canadian and European production. Cent. Eur. For. J. 2010, 56, 337-347. [CrossRef]

39. Galko, J.; Nikolov, C.; Kunca, A.; Vakula, J.; Gubka, A.; Zubrik, M.; Rell, S.; Konôpka, B. Effectiveness of pheromone traps for the European spruce bark beetle: A comparative study of four commercial products and two new models. Cent. Eur. For. J. 2016, 62, 207-215. [CrossRef]

40. Abgrall, J.F. Utilisation de phéromones artificielles contre Ips typographus. EPPO Bull. 1986, 16, 633-637. [CrossRef]

41. Faccoli, M.; Stergulc, F. Ips typographus (L.) pheromone trapping in south Alps: Spring catches determine damage thresholds. J. Appl. Entomol. 2004, 128, 307-311. [CrossRef]

42. Faccoli, M.; Stergulc, F. Damage reduction and performance of mass trapping devices for forest protection against the spruce bark beetle, Ips typographus (Coleoptera Curculionidae Scolytinae). Ann. For. Sci. 2008, 65, 1-9. [CrossRef] 
43. Grégoire, J.C.; Raty, L.; Drumont, A.; de Windt, N. Pheromone mass trapping: Does it protect windfalls from attack by Ips typographus L. (Coleoptera: Scolytidae). In Integrating Cultural Tactics into the Management of Bark Beetle and Reforestation Pests; USDA Forest Service General Technical Report NE-236; USDA: Vallombrosa, Italy, 1997; pp. 1-8.

44. Jakuš, R. A method for the protection of spruce stands against Ips typographus by the use of barriers of pheromone traps in north-eastern Slovakia. Anz. Schädlkd. Pflanzenschutz Umweltschutz 1998, 71, 152-158. [CrossRef]

45. Weslien, J. Effects of mass trapping on Ips typographus (L.) populations. J. Appl. Entomol. 1992, 114, 228-232. [CrossRef]

46. Dimitri, L.; Gebauer, U.; Lösekrug, R.; Vaupel, O. Influence of mass trapping on the population dynamic and damage-effect of bark beetles. J. Appl. Entomol. 1992, 114, 103-109. [CrossRef]

47. Pfister, A.; Hueber, W. Eignung von Pheromonfallen zur Borkenkäferbekämpfung im fünfjährigen Dauerversuch. Forstschutz Aktuell 2008, 43, 7-11.

48. Matyjaszczyk, E.; Karmilowicz, E.; Skrzecz, I. How European Union accession and implementation of obligatory integrated pest management influenced forest protection against harmful insects: A case study from Poland. For. Ecol. Manag. 2019, 433, 146-152. [CrossRef]

49. Weslien, J.; Regnander, J. The influence of natural enemies on brood production in Ips typographus (Col. scolytidae) with special reference to egg-laying and predation by Thanasimus formicarius (Col: Cleridae). Entomophaga 1992, 37, 333-342. [CrossRef]

50. Hulcr, J.; Ubik, K.; Vrkoc, J. The role of semiochemicals in tritrophic interactions between the spruce bark beetle Ips typographus, its predators and infested spruce. J. Appl. Entomol. 2006, 130, 275-283. [CrossRef]

51. Göthlin, E.; Schroeder, L.M.; Lindelöw, A. Attacks by Ips typographus and Pityogenes chalcographus on windthrown spruces (Picea abies) during the two years following a storm felling. Scand. J. For. Res. 2000, 15, 542-549. [CrossRef]

52. Byers, J.A. Orientation of bark beetles Pityogenes chalcographus and Ips typographus to pheromonebaited puddle traps placed in grids: A new trap for control of scolytids. J. Chem. Ecol. 1993, 19, 2297-2316. [CrossRef] [PubMed]

53. Byers, J.A. Avoidance of competition by spruce bark beetles, Ips typographus and Pityogenes chalcographus. Experientia 1993, 49, 272-275. [CrossRef]

54. Lompe, A. Die Käfer Mitteleuropas. Ein Bestimmungswerk im Internet: Gattung: Ips De Geer. 2020. Available online: http:/ / coleonet.de/coleo/texte/ips.htm (accessed on 30 January 2021).

55. Lompe, A. Die Käfer Mitteleuropas. Ein Bestimmungswerk im Internet: Gattung Pityogenes. 2021. Available online: http: // coleonet.de/coleo/texte/pityogenes.htm (accessed on 4 February 2021).

56. Thomaes, A.; Drumont, A.; Warzee, N.; Grégoire, J.-C.; Stassen, E.; Crevecoeur, L.; Berckvens, N.; Casteels, H.; van de Vijver, D.; Raemdonck, H. Ecology and distribution of Thanasimus formicarius (Linnaeus, 1758) and the newly discovered Thanasimus femoralis (Zetterstedt, 1828) in Belgium. Bull. Ann. Soc. R. Belge Entomolog. 2017, 153, 206-214.

57. Grüne, S. Handbuch zur Bestimmung der Europäischen Borkenkäfer: Brief Illustrated Key to European Bark Beetles; M. \& H. Schaper: Hannover, Germany, 1979.

58. Wehnert, M.; Müller, M. 'Allochthonous Kairomones' in stands of European beech (Fagus sylvatica)-Approach for nature-based bark beetle management with clerid beetles (Thanasimus spp.). Biol. Control 2012, 62, 16-23. [CrossRef]

59. Wehnert, M. Analyse und Olfaktorische Steuerung Bast- und Holzbesiedelnder Sowie Diese Natürlich Regulierender Zoophager Insekten an Laubbäumen als Grundlage für Ein Zukunftsfähiges und Nachhaltiges Risikomanagement. Ph.D. Thesis, Technische Universität Dresden, Dresden, Germany, 24 February 2014.

60. Helbig, C.; Heber, T. Chemical sabotage in forest health management: Effects of Allium ursinum L. based semiochemicals on the catches of bark beetles and their antagonists in stands of European ash (Fraxinus excelsior L.). Mitt. Dtsch. Ges. Allg. Angew. Entomol. 2020, 22, 269-272.

61. Schlyter, F.; Byers, J.A.; Löfqvist, J. Attraction to pheromone sources of different quantity, quality, and spacing: Density-regulation mechanisms in bark beetle Ips typographus. J. Chem. Ecol. 1987, 13, 1503-1523. [CrossRef] [PubMed]

62. Miller, D.R.; Crowe, C.M.; Barnes, B.F.; Gandhi, K.J.K.; Duerr, D.A. Attaching lures to multiple-funnel traps targeting saproxylic beetles (Coleoptera) in pine stands: Inside or outside funnels? J. Econ. Entomol. 2013, 106, 206-214. [CrossRef] [PubMed]

63. Zumr, V. Effect of synthetic pheromones Pheroprax on the coleopterous predators of the spruce bark beetle Ips typographus (L.). J. Appl. Entomol. 1983, 95, 47-50. [CrossRef]

64. Franklin, A.J.; Grégoire, J.C. Dose-dependent response and preliminary observations on attraction range of Ips typographus to pheromones at low release rates. J. Chem. Ecol. 2001, 27, 2425-2435. [CrossRef] [PubMed]

65. Hrasovec, B.; Kasumovic, L.; Franjevic, M. Overwintering of eight toothed spruce bark beetle (Ips typographus) in spruce forests of North Velebit. Croat. J. For. Eng. 2011, 32, 211-222.

66. Nakládal, O.; Sova, J. Comparison of two types of ECOLURE lure on Ips typographus (L.) (Coleoptera: Scolytidae). J. For. Sci. 2010, 56, 609-613. [CrossRef]

67. Jakuš, R.; Simko, J. The use of dispensers with different release rates at pheromone trap barriers for Ips typographus. Anz. Schädlkd. Pflanzenschutz Umweltschutz 2000, 73, 33-36.

68. Pfister, A. Borkenkäferpheromontests 1997. Report 1997. Available online: https://bfw.ac.at/rz/bfwcms.web?dok=6463 (accessed on 20 February 2020).

69. Pfister, A. Borkenkäferpheromontests 1998. Report 1998. Available online: https:/ bfw.ac.at/rz/bfwcms.web?dok=6473 (accessed on 20 February 2020). 
70. Otto, L.F. Untersuchungen zur Fangleistung Verschiedener Dispenser für den Buchdrucker und Kupferstecher. Report 2005. Available online: https://docplayer.org/161657598-Untersuchungen-zur-fangleistung-verschiedener-dispenser-fuer-denbuchdrucker-und-kupferstecher-html (accessed on 20 February 2020).

71. Šramel, N.; Kavčič, A.; Kolšek, M.; Groot, M. Estimating the most effective and economical pheromone for monitoring the European spruce bark beetle. J. Appl. Entomol. 2021, 145, 312-325. [CrossRef]

72. Thüringen Forst. Bericht über Ergebnisse zur Anlockung des Buchdruckers (Ips typographus) mit Verschiedenen Lockstoffdispensern im Jahr 2008. Report 2008.

73. Harper, J.K.; Arif, A.M.; Grant, D.M. cis-Verbenol. Acta Crystallogr. C Cryst. Struct. Commun. 2000, 56, 451-452. [CrossRef]

74. Lindgren, B.S. A multiple funnel trap for scolytid beetles (Coleoptera). Can. Entomol. 1983, 115, 299-302. [CrossRef]

75. Niemeyer, H.; Schröder, T.; Watzek, G. Eine neue Lockstoff-Falle zur Bekämpfung von rinden- und holzbrütenden Borkenkäfern. Forst-Holzwirt 1983, 38, 105-112.

76. Wickham, H. The split-apply-combine strategy for data analysis. J. Stat. Softw. 2011, 40, 1-29. [CrossRef]

77. Wickham, H. Elegant Graphics for Data Analysis; Springer: New York, NY, USA, 2016.

78. Wickham, H.; Averick, M.; Bryan, J.; Chang, W.; McGowan, L.; François, R.; Grolemund, G.; Hayes, A.; Henry, L.; Hester, J.; et al. Welcome to the Tidyverse. J. Open Source Softw. 2019, 4, 1-6. [CrossRef]

79. Kassambara, A. ggpubr: “ggplot2" Based Publication Ready Plots. R Package Version 0.4.0. 2020. Available online: https: //joss.theoj.org/papers/10.21105/joss.01686 (accessed on 29 October 2021).

80. Giraudoux, P. pgirmess: Spatial Analysis and Data Mining for Field Ecologists. R Package Version 1.7.0. 2021. Available online: https: / / cran.r-project.org/web / packages/pgirmess/index.html (accessed on 29 October 2021).

81. Pohlert, T. PMCMRplus: Calculate Pairwise Multiple Comparisons of Mean Rank Sums Extended. R Package Version 1.9.0. 2021. Available online: https:/ / cran.r-project.org/web/packages /PMCMRplus/index.html (accessed on 29 October 2021).

82. Wickham, H.; Bryan, J. readxl: Read Excel Files. R Package Version 1.3.1. 2019. Available online: https://cran.r-project.org/web/ packages/readxl/index.html (accessed on 29 October 2021).

83. Wood, D.L.; Vité, J.P. Studies on the host selection behavior of Ips confusus (LeConte) (Coleoptera: Scolytidae) attacking Pinus ponderosa. Contr. Boyce. Thompson Inst. Pl. Res. 1961, 21, 79-95.

84. Wood, D.L.; Bushing, R.W. The olfactory response of Ips confusus (LeConte) (Coleoptera: Scolytidae) to the secondary attraction in the laboratory. Can. Entomol. 1963, 95, 1066-1078. [CrossRef]

85. Silverstein, R.M.; Rodin, J.O.; Wood, D.L. Sex attractants in frass produced by male Ips confusus in Ponderosa Pine. Science 1966, 154, 509-510. [CrossRef]

86. Wood, D.L.; Browne, L.E.; Bedard, W.D.; Tilden, P.E.; Silverstein, R.M.; Rodin, J.O. Response of Ips confusus to synthetic sex pheromones in nature. Science 1967, 159, 1373-1374. [CrossRef] [PubMed]

87. Bakke, A. Evidence of a population aggregating pheromone in Ips typographus (Coleoptera: Scolytidae). Contr. Boyce. Thompson Inst. Pl. Res. 1970, 24, 309-310.

88. Vité, J.P.; Bakke, A.; Renwick, J.A.A. Pheromones in Ips (Coleoptera: Scolytidae): Occurrence and production. Can. Entomol. 1972, 104, 1967-1975. [CrossRef]

89. Rudinsky, J.A.; Novák, V.; Švihra, P. Attraction of the bark beetle Ips typographus L. to terpenes and a male-produced pheromone. J. Appl. Entomol. 1971, 67, 179-188. [CrossRef]

90. Vité, J.P.; Francke, W. The aggregation pheromones of bark beetles: Progress and problems. Naturwissenschaften 1976, 63, 550-555. [CrossRef]

91. Voolma, K. Comparison of two traps used for monitoring large pine weevil populations, Hylobius abietis L. (Coleoptera: Curculionidae). Trans. Est. Agric. Univ. Agron. 2000, 209, 233-235.

92. Schlyter, F.; Löfqvist, J.; Byers, J.A. Behavioural sequence in the attraction of the bark beetle Ips typographus to pheromone sources. Physiol. Entomol. 1987, 12, 185-196. [CrossRef]

93. Andersson, M.N.; Larsson, M.C.; Schlyter, F. Specificity and redundancy in the olfactory system of the bark beetle Ips typographus: Single-cell responses to ecologically relevant odors. J. Insect. Physiol. 2009, 55, 556-567. [CrossRef]

94. Sun, X.; Yang, Q.; Sweeney, J.D.; Gao, C. A review chemical ecology of Ips typographus (Coleoptera, Scolytidae). J. For. Res. 2006, 17, 65-70. [CrossRef]

95. Schlyter, F.; Birgersson, G.; Byers, J.A.; Löfqvist, J.; Bergström, G. Field response of spruce bark beetle, Ips typographus, to aggregation pheromone candidates. J. Chem. Ecol. 1987, 13, 701-716. [CrossRef] [PubMed]

96. Dickens, J.C. Behavioural and electrophysiological responses of the bark beetle, Ips typographus, to potential pheromone components. Physiol. Entomol. 1981, 6, 251-261. [CrossRef]

97. Olenici, N.; Duduman, M.-L.; Olenici, V. Inhibitory Effect of (-)Alpha Pinene High Release Rates on Ips typographus (L.) Response to its Aggregation Pheromone. An. ICAS 2007, 50, 203-212.

98. Jönsson, A.M.; Schroeder, L.M.; Lagergren, F.; Anderbrant, O.; Smith, B. Guess the impact of Ips typographus-An ecosystem modelling approach for simulating spruce bark beetle outbreaks. Agric. For. Meteorol. 2012, 166-167, 188-200. [CrossRef]

99. Berec, L.; Doležal, P.; Hais, M. Population dynamics of Ips typographus in the Bohemian Forest (Czech Republic): Validation of the phenology model PHENIPS and impacts of climate change. For. Ecol. Manag. 2013, 292, 1-9. [CrossRef]

100. Wermelinger, B.; Seifert, M. Analysis of the temperature dependent development of the spruce bark beetle Ips typographus (L) (Col., Scolytidae). J. Appl. Entomol. 1998, 122, 185-191. [CrossRef] 
101. Baier, P.; Pennerstorfer, J.; Schopf, A. PHENIPS-A comprehensive phenology model of Ips typographus (L.) (Col., Scolytinae) as a tool for hazard rating of bark beetle infestation. For. Ecol. Manag. 2007, 249, 171-186. [CrossRef]

102. Niemeyer, H.; Watzek, G. Test von Monoterpenen als Zusatz zu Pheroprax ${ }^{\circledR}$ bzw. Chalcoprax ${ }^{\circledR}$ in Pheromonfallen zum Fang des Buchdruckers, Ips typographus L. bzw. des Kupferstechers, Pityogenes chalcographus L. (Col., Scolytidae). Anz. Schädlkd. Pflanzenschutz Umweltschutz 1996, 69, 109-110. [CrossRef]

103. Birgersson, G.; Schlyter, F.; Löfqvist, J.; Bergström, G. Quantitative variation of pheromone components in the spruce bark beetle Ips typographus from different attack phases. J. Chem. Ecol. 1984, 10, 1029-1055. [CrossRef]

104. Wermelinger, B. Ecology and management of the spruce bark beetle Ips typographus-A review of recent research. For. Ecol. Manag. 2004, 202, 67-82. [CrossRef]

105. Bakke, A.; Kvamme, T. Kairomone response in Thanasimus predators to pheromone components of Ips typographus. J. Chem. Ecol. 1981, 7, 305-312. [CrossRef] [PubMed]

106. Tømmerås, B. Specialization of the olfactory receptor cells in the bark beetle Ips typographus and its predator Thanasimus formicarius to bark beetle pheromones and host tree volatiles. J. Comp. Physiol. 1985, 157, 335-341. [CrossRef]

107. Hansen, K. Reception of bark beetle pheromone in the predaceous clerid beetle, Thanasimus formicarius (Coleoptera: Cleridae). J. Comp. Physiol. 1983, 150, 371-378. [CrossRef]

108. Warzee, N.; Grégoire, J.-C. Thanasimus formicarius (Coleoptera: Cleridae): Why a large range of prey for a specialized predator? In Proceedings of the IUFRO Kanazawa 2003 "Forest Insect Population Dynamics and Host Influences", Kanazawa, Japan, 14-19 September 2003; pp. 16-18.

109. Zahradník, P.; Zahradníková, M. Evaluation of the efficacy duration of different types of pheromone dispensers to lure Ips typographus (L.) (Coleoptera: Curculionidae: Scolytinae). J. For. Sci. 2014, 60, 456-463. [CrossRef]

110. Nakládal, O.; Senfeld, P.; Franjevic, M.; Uhlikova, H. Comparison of all season and standard type of ECOLURE ${ }^{\circledR}$ dispenser efficacy in trap catches of Europaean spruce bark beetle (Ips typographus L.). J. For. Soc. Croatia 2013, 137, 395-400.

111. Ditz, H.M.; Nieder, A. Numerosity representations in crows obey the Weber-Fechner law. Proc. Biol. Sci. 2016, 283, 1-9. [CrossRef] [PubMed]

112. Müller, M. Untersuchungen zur Attraktion und Repulsion des Großen Braunen Rüsselkäfers, Hylobius abietis L. (Coleoptera, Curculionidae). Ph.D. Thesis, Technische Universität Dresden, Dresden, Germany, 23 June 1993.

113. Park, J.; Reid, M.L. Distribution of a bark beetle, Trypodendron lineatum, in a harvested landscape. For. Ecol. Manag. 2007, 242, 236-242. [CrossRef]

114. Wright, R.H. Some quantitative aspects of insect attraction. Can. Entomol. 1966, 98, 1114-1117. [CrossRef]

115. Altenkirch, W.; Bogenschütz, H. Waldschutz auf Ökologischer Grundlage: 86 Tabellen; Ulmer: Stuttgart (Hohenheim), Germany, 2002.

116. Helmund, M. Aggregation von Borkenkäferprädatoren unter Ausnutzung des Prinzips der Allochthonen Kairomone in Ausgewählten Nadelwaldhabitaten unter Besonderer Berücksichtigung der Ameisenbuntkäfer. Ph.D. Thesis, Technische Universität Dresden, Dresden, Germany, 8 April 2013.

117. Schumacher, J.; Pohris, V. Der Kleine Buchenborkenkäfer als relevanter Rindenbrüter in Schwarzerlen-Beständen. Allg Forst Jagdztg 2000, 14, 760-763.

118. Flechtmann, C.A.H.; Ottati, A.L.T.; Berisford, C.W. Comparison of four trap types for ambrosia beetles (Coleoptera, Scolytidae) in Brazilian eucalyptus stands. J. Econ. Entomol. 2000, 93, 1701-1707. [CrossRef]

119. Miller, D.R.; Crowe, C.M. Relative performance of Lindgren multiple-funnel, intercept panel, and colossus pipe traps in catching Cerambycidae and associated species in the southeastern United States. J. Econ. Entomol. 2011, 104, 1934-1941. [CrossRef] [PubMed]

120. Petrice, T.; Haack, R.; Poland, T. Evaluation of three trap types and five lures for monitoring Hylurgus ligniperda (Coleoptera: Scolytidae) and other local scolytids in New York. Great Lakes Entomol. 2018, 37, 1-9.

121. Dodds, K.J.; Dubois, G.D.; Hoebeke, E.R. Trap type, lure placement, and habitat effects on Cerambycidae and Scolytinae (Coleoptera) catches in the Northeastern United States. J. Econ. Entomol. 2010, 103, 698-707. [CrossRef] [PubMed]

122. McIntosh, R.L.; Katinic, P.J.; Allison, J.D.; Borden, J.H.; Downey, D.L. Comparative efficacy of five types of trap for woodborers in the Cerambycidae, Buprestidae and Siricidae. Agric. For. Entomol. 2001, 3, 113-120. [CrossRef]

123. Lindgren, B.S.; Fraser, R.G. Control of ambrosia beetle damage by mass trapping at a dryland log sorting area in British Columbia. For. Chron. 1994, 70, 159-163. [CrossRef]

124. Zumr, V. Dispersal of the spruce bark beetle Ips typographus (L.) (Col., Scolytidae) in spruce woods. J. Appl. Entomol. 1992, 114, 348-352. [CrossRef]

125. Goyer, R.A.; Lenhard, G.J.; Strom, B.L. The influence of silhouette color and orientation on arrival and emergence of Ips pine engravers and their predators in loblolly pine. For. Ecol. Manag. 2004, 191, 147-155. [CrossRef]

126. Zumr, V.; Soldan, T. Reproductive cycles of Ips typographus, Ips amitinus and Pityogenes chalcographus (Coleoptera, Scolytidae). Acta Entomol. Bohemoslov. 1981, 78, 280-289.

127. McCravy, K.W.; Nowak, J.T.; Douce, G.K.; Berisford, C.W. Evaluation of multiple-funnel and slot traps for collection of southern pine bark beetles and predators. J. Entomol. Sci. 2000, 35, 77-82. [CrossRef]

128. Martín, A.; Etxebeste, I.; Pérez, G.; Álvarez, G.; Sánchez, E.; Pajares, J. Modified pheromone traps help reduce bycatch of bark-beetle natural enemies. Agric. For. Entomol. 2013, 15, 86-97. [CrossRef] 
129. Mills, N.J. Some observations on the role of predation in the natural regulation of Ips typographus populations. J. Appl. Entomol. 1985, 99, 209-215. [CrossRef]

130. Raty, L.; Drumont, A.; de Windt, N.; Grégoire, J.C. Mass trapping of the spruce bark beetle Ips typographus L.: Traps or trap trees? For. Ecol. Manag. 1995, 78, 191-205. [CrossRef] 